\title{
Ovarian Granulosa Cell Tumor: A Clinicopathological Series
}

\section{Mark R Brincat ${ }^{1}{ }^{*}$, David Pisani ${ }^{1}$, Donika Metaraku ${ }^{2}$, Rachel Micallef ${ }^{2}$, Yves Muscat Baron ${ }^{1}$, Eleanor Borg $^{1}$, Annelise Aquilina ${ }^{1}$, James Degaetano ${ }^{1}$ and Salvina Zrinzo ${ }^{1}$}

${ }^{1}$ Mater Dei Hospital, Msida, Malta

${ }^{2}$ Sir Anthony Mamo Oncology Hospital, Msida, Malta

*Corresponding author: Dr. Mark R Brincat, MD, MSc, Mater Dei Hospital, E-mail: mark.a.brincat@gov.mt

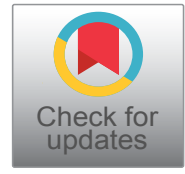

\section{Introduction}

Granulosa cell tumours (GCT) are uncommon neoplasms, accounting for 2-5\% of all ovarian carcinomas [1]. The pathogenesis of these tumours is characterised by differentiation towards the follicular granulosa cell. However, the exact cell of origin is disputed, with the granulosa cell, thecal cell or fibroblast having been proposed as putative progenitors. A granulosa stem-cell has been described, which has also been suggested as a cell of origin [2].

Approximately $65 \%$ of patients are postmenopausal at the time of diagnosis [2] and, in these patients, the morphology of the tumour conforms to the so-called adult-type GCT. A minority of tumours, however, present at a younger age, and these tumours typically exhibit juvenile-type GCT morphology. However, this is by no means a pathological dogma and both tumour forms have been described at any age $[1,2]$.

This case series includes all cases of ovarian GCT diagnosed at Mater Dei Hospital, Malta, between 2008 and 2016. GCT cases were identified through the hospital histopathological records after the appropriate data protection clearance. This case series aims to showcase the variable natural history and presenting features of juvenile-type and adult-type GCTs, while emphasising the need for indefinite long-term follow up protocols.

\section{Case Series}

\section{Case 1}

A 16-year-old female, diagnosed with polycystic ovarian syndrome, was being treated with a combined oral contraceptive in view of irregular cycles. In 2013, a $6 \mathrm{~cm}$ cyst was identified in the left ovary, which grew to $9 \mathrm{~cm}$ on follow-up ultrasound eight weeks later. She was scheduled for elective ovarian cystectomy but presented a few days later with acute abdominal pain. Computed tomography (CT) showed a $13 \mathrm{~cm}$ cyst with secondary left hydroureteronephrosis. Tumour marker levels were within normal limits. An emergency laparotomy was performed using an infraumbilical midline incision. $1.7 \mathrm{~L}$ of blood-tinged free fluid was suctioned from the pelvic cavity and left salpingo-oophorectomy was performed. Histopathology of the cyst showed a juvenile-type GCT with a mitotic index of 19 mitotic figures per 10 high power fields.

Follow up serological and radiological investigations were unremarkable for four years until 2017, when ultrasonography identified a $9 \mathrm{~cm}$ multilocular mass in the pouch of Douglas. This was associated with a normal serum inhibin B level of $120 \mathrm{ng} / \mathrm{L}(12-190 \mathrm{ng} / \mathrm{L})$. The patient was referred to Charing Cross Hospital (London) where she underwent laparoscopic cystectomy with preservation of the right ovary. This was confirmed to be GCT recurrence.

\section{Case 2}

A 16-year-old previously healthy female presented to the emergency department in 2016 with a threemonth history of amenorrhea and intermittent abdominal discomfort. Examination revealed a pelvic mass extending up to the xiphoid process, confirmed on CT to be a multiseptated cyst with solid and cystic components, associated with right hydroureteronephrosis (Figure 1a). A raised CA 19.9 level of $76.1 \mathrm{U} / \mathrm{mL}(0-33$ 


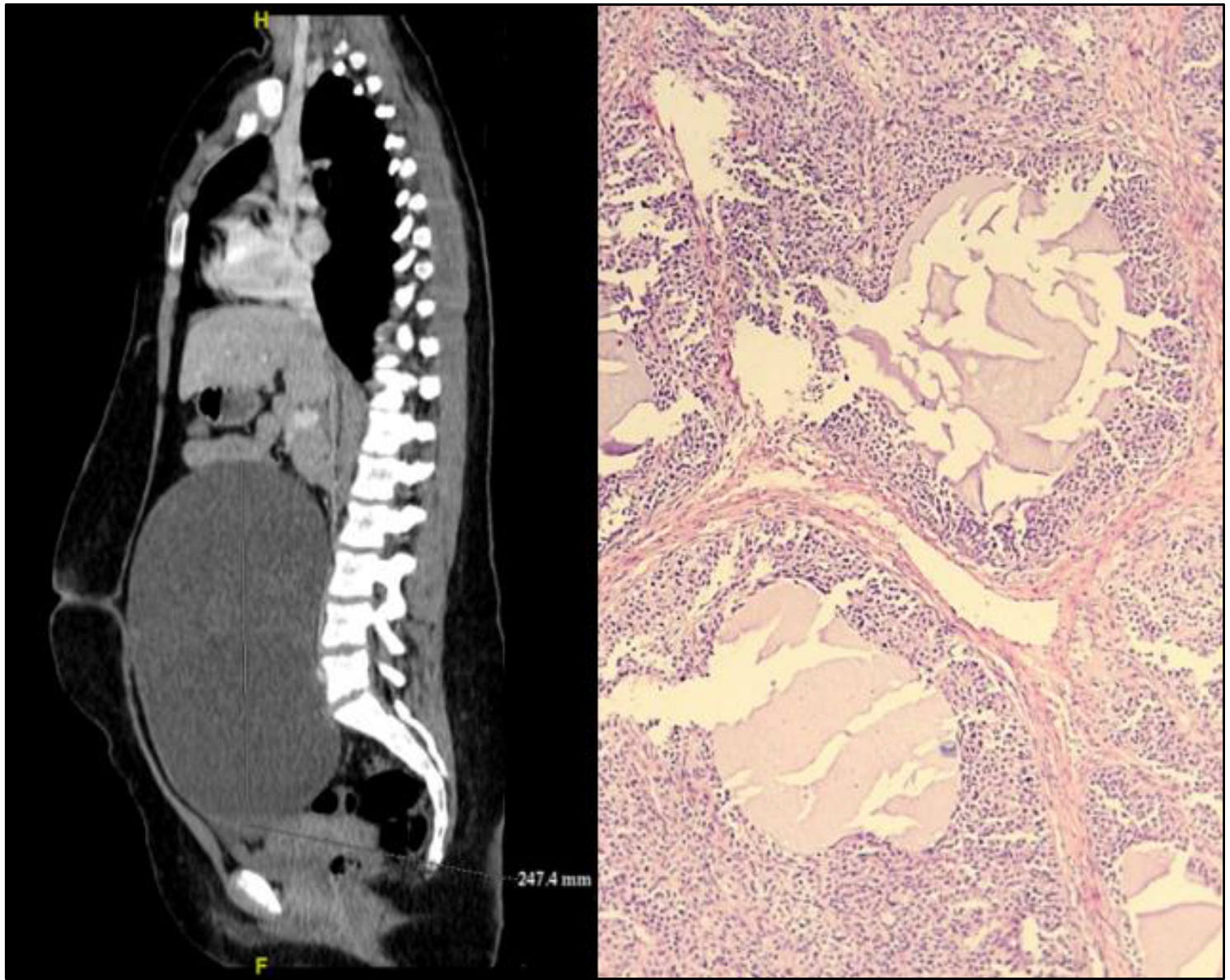

Figure 1: a) Sagittal CT image showing a large $(25 \times 20 \times 14 \mathrm{~cm}$; craniocaudal, transverse, anteroposterior $)$ cystic mass with fine septations arising from the pelvis; b) Medium power view of the juvenile GCT highlighting the microcytic growth pattern (H\&E x200).

$\mathrm{U} / \mathrm{mL}$ ) was noted, although other markers were normal. The patient was scheduled for urgent outpatient follow-up however re-presented three days later with severe abdominal pain. Emergency laparotomy showed an irregular left ovarian cyst, the posterior aspect of which was disrupted, together with approximately $2 \mathrm{~L}$ of blood-tinged fluid in the peritoneal cavity. The mass had a multicystic cut surface, with the subcysts containing serosanguinous fluid and solid areas. Histology showed a juvenile-type GCT with a mitotic index of $17 \mathrm{MF} / 10$ HPF (Figure 1b). Right ovarian biopsies and omental biopsies were also taken but did not show evidence of tumour. Surveillance has, till now, been unremarkable with normal Inhibin B levels and MR imaging (Figure S1).

\section{Case 3}

A 30-year-old female was referred in 2012 with primary infertility associated with a four-month history of metrorrhagia. A $16 \mathrm{~cm}$ right ovarian cystic mass was noted on ultrasonography. Tumour marker levels were normal. A right salpingo-oophorectomy was performed, removing a torted right cystic mass, the pathological analysis of which showed an adult-type GCT. Unfortunately, the patient was lost to follow up until 2016, when she re-presented with a five-month history of metrorrhagia and abdominal distension. A $7 \mathrm{~cm}$ left adnexal cyst with irregular borders was identified on ultrasonography, as- sociated with a raised inhibin B level of $580 \mathrm{ng} / \mathrm{L}$ (12-190 $\mathrm{ng} / \mathrm{L})$. Computed tomography was performed and did not identify any distant metastatic involvement. Laparotomy showed an enlarged left ovary distorted by a perforated tumour, with multiple small deposits on the ovarian capsule. Total abdominal hysterectomy, left salpingo-oophorectomy and infracolic omentectomy was thus performed, the histopathological analysis of which also showed an adult GCT, identical to that described for the right ovarian mass excised four years previously. The omentum was also positive for GCT. The patient refused chemotherapeutic treatment.

The patient has had an unremarkable follow up with regular tumour markers (including AMH and Inhibin B) and MR imaging of the abdomen and pelvis.

\section{Case 4}

A 35-year-old female was referred in 2016 in view of a four-month history of amenorrhea. She had been diagnosed with a right adnexal cyst (suspected dermoid) one year earlier at a different centre. Magnetic resonance imaging of the pelvis confirmed the isolated presence of a $3 \mathrm{~cm}$ mass in the left ovary, which was laparoscopically shelled out. Histological analysis of the mass showed an adult-type GCT with a mitotic index of $3 \mathrm{MF} / 10 \mathrm{HPF}$, in view of which completion right 


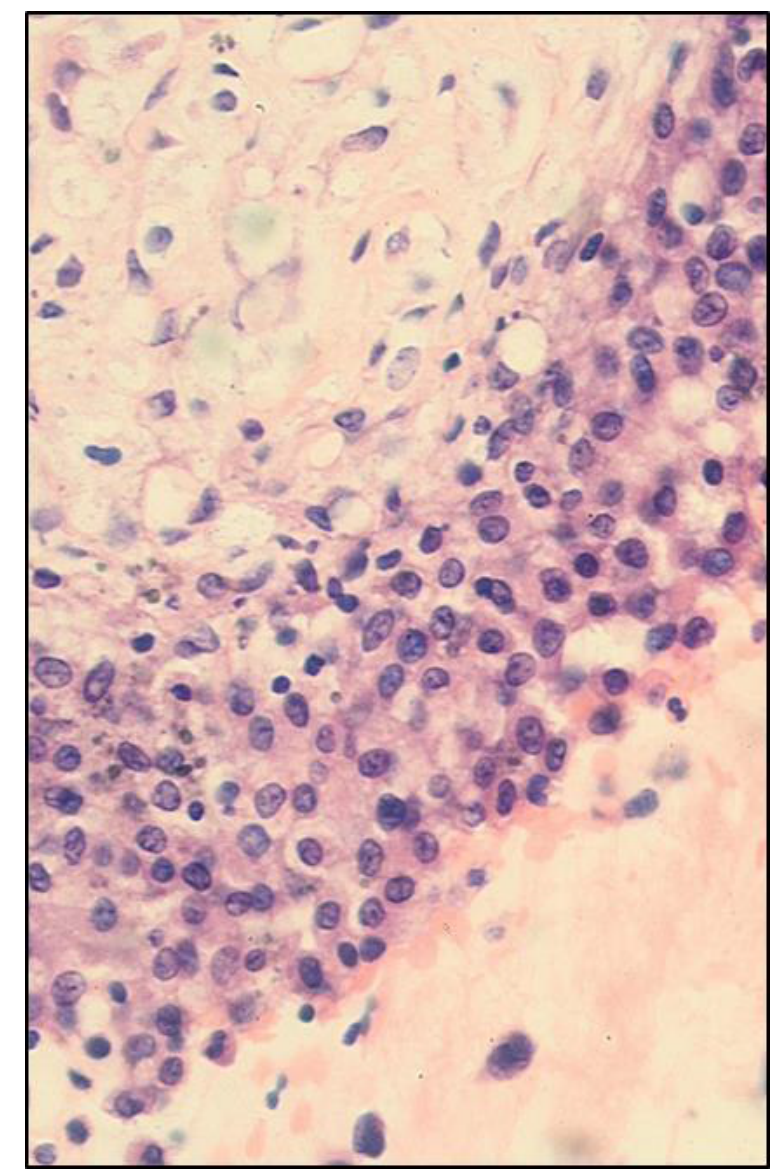

Figure 2: High power view of a cell block of the peritoneal fluid sample, showing round to ovoid GCT cells with a bland, focally clumped chromatin pattern, and occasional linear nuclear grooves (H\&E x400).

salpingo-oophorectomy, omental biopsy and peritoneal washing was carried out. Neoplastic granulosa cells were identified on peritoneal fluid cytology, highlighted on inhibin immunohistochemistry. Follow up with regular tumour markers (including AMH and Inhibin B) and MR imaging of the abdomen and pelvis have been unremarkable for the past year (Figure 2).

\section{Case 5}

A 54-year-old female underwent laparoscopic-assisted vaginal hysterectomy and bilateral salpingo-oophorectomy in 2013 due to persistent postmenopausal bleeding (PMB) despite normal endometrial biopsies. Intraoperatively, the uterus was slightly bulky and adnexa were macroscopically healthy.

Pathological analysis showed multiple leiomyomas together with a $1.3 \mathrm{~cm}$ right ovarian cyst containing haemorrhagic fluid. Histological analysis of the cyst showed an adult-type GCT with a low mitotic index of $2 \mathrm{MF} / 10$ HPF. The uterine cavity contained weakly proliferative endometrium and two hyperplastic polyps characterised by irregular and focally dilated proliferative glands. Routine follow up has been uneventful to date.

\section{Case 6}

A 58-year-old female was referred in 2015 in view of a two-year history of recurrent PMB. She had previously been reluctant to undergo endometrial sampling despite thickened endometrium on ultrasonography. Repeat ultrasonography showed an endometrial thickness of $2.3 \mathrm{~cm}$ together with an $8.4 \mathrm{~cm}$ mass in the rectouterine pouch.

Total abdominal hysterectomy with bilateral salpingo-oophorectomy (TAH-BSO), omentectomy and umbilical hernia repair was performed. A small, solid right ovarian mass was noted, with no definite evidence of peritoneal deposits. The left ovary was also distended. Histopathological analysis of the right ovarian mass showed an adult-type GCT and an incidental left ovarian dermoid cyst was identified. The endometrium showed hyperplasia with endometrial intraepithelial neoplasia, together with an endometrial polyp. Clinical, biochemical and radiological follow-up has been unremarkable for the past two years.

\section{Case 7}

A 56-year-old female presented in October 2015 with a two-month history of abdominal pain and decreased appetite. She gave a history of adult-type ovarian GCT treated twenty-nine years earlier by a right salpingo-oophorectomy. CT showed two abdominal masses adjacent to the left renal bed and immediately inferior to the left liver lobe.

CT-guided biopsy of one of the masses showed spindle cells embedded in a loose myxoid stroma, which were negative for an extensive immunohistochemical panel. A possibility of low-grade fibromyxoid sarcoma was thus raised. At laparotomy, one mass was identified adherent to the lesser omentum while the other encased the splenic artery, hence requiring a combined splenectomy. Both masses were shown to conform histologically to adult-type GCT with focal spindle-cell morphology. The conventional areas of the tumour expressed inhibin and ER, while the spindle cell areas did not, explaining the diagnostic discrepancy with the original biopsy.

The patient was treated adjuvantly with bleomycin, etoposide and cisplatin (BEP). Restaging following two cycles showed an inhomogeneous $3.6 \mathrm{~cm}$ posterior mediastinal mass and a similarly-sized peritoneal mass close to the pancreatic tail. Two further cycles of BEP therapy were administered, with radiological follow-up showing stable disease.

\section{Case 8}

A 67-year-old female presented in 2013 with PMB. Endometrial biopsy was carried out due to an endometrial thickness of $1.7 \mathrm{~cm}$ on ultrasound. This showed endometrial hyperplasia without atypia. Bleeding persisted despite continuous progestogen therapy. Repeat ultrasonography identified a $6 \mathrm{~cm}$ complex right adnexal cyst. Tumour markers were within normal limits. 

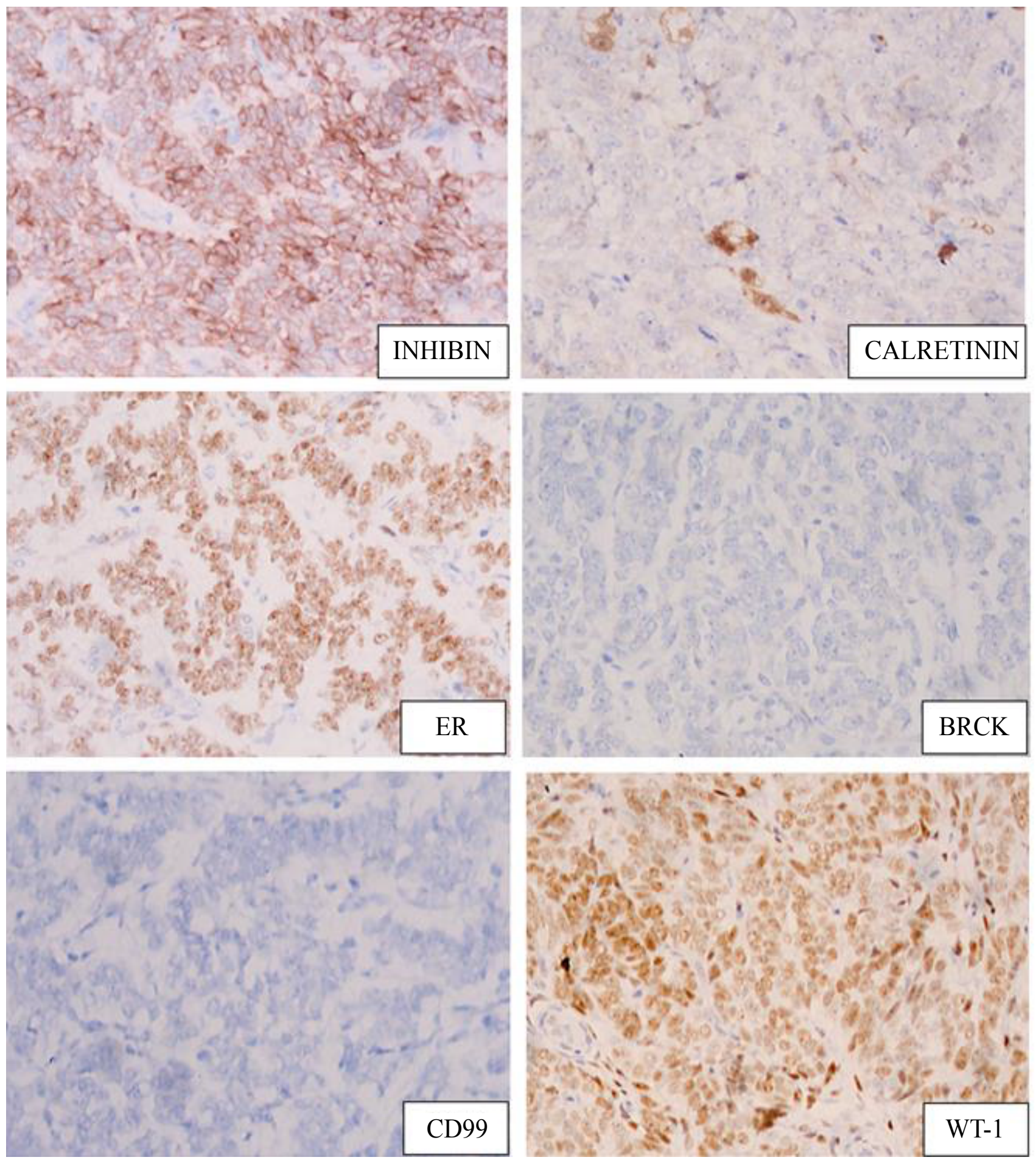

Figure 3: Immunohistochemical panel for the tumour showing diffuse positivity for inhibin, ER and WT-1, focal positivity for calretinin and negativity for cytokeratin (BRCK) and CD99 (x400).

TAH-BSO was subsequently carried out, the histological analysis of which showed a right ovarian adult-type GCT (Figure 3). The histology of granulosa cell tumours is highly variable, with the tumour adopting multiple growth patterns and configurations. Morphological overlap with other sex-cord tumours, including Sertoli cell tumours, is not infrequently encountered and the characteristic nuclear grooves may not always be conspicuous. Hence, immunohistochemical staining is often performed to confirm the granulosa cell lineage of the tumour, with expression of inhibin, vimentin, calretinin, CD99 and WT-1 being commonly encountered, as shown in Figure 3 below. The endometrium showed pseudodecidualization, in keeping with progestogen effects. Follow up has been unremarkable for the past four years (Figure S2).

\section{Discussion}

Ovarian GCTs are rare neoplasms characterized by their indolent behaviour and favourable prognosis. Recent evidence has shown association of this tumour with Forkhead box L2 gene mutations. This gene encodes a transcription factor that is important in ovarian development, being expressed primarily during gonadogen- 
Table 1: Summarized case details for the presented series.

\begin{tabular}{|c|c|c|c|c|c|c|}
\hline Case & Age & Year & Presenting features & $\begin{array}{l}\text { Tumour histology and } \\
\text { highlights }\end{array}$ & $\begin{array}{l}\text { Other pathological } \\
\text { findings }\end{array}$ & Follow up \\
\hline 1 & 16 & 2013 & $\begin{array}{l}\text { Acute cyst rupture before } \\
\text { planned elective surgery }\end{array}$ & $\begin{array}{l}\text { Juvenile GCT } \\
\text { Mitotic activity: } 19 \text { MF/10 HPF }\end{array}$ & N/A & $\begin{array}{l}\text { Recurrence in } \\
\text { pouch of Douglas } \\
4 \text { years after } \\
\text { diagnosis }\end{array}$ \\
\hline 2 & 16 & 2016 & $\begin{array}{l}\text { Amenorrhea. Acute cyst rupture } \\
\text { before planned elective surgery }\end{array}$ & $\begin{array}{l}\text { Juvenile GCT } \\
\text { Mitotic activity: } 17 \text { MF/10 HPF }\end{array}$ & N/A & $\begin{array}{l}\text { No recurrence to } \\
\text { date }\end{array}$ \\
\hline 3 & 30 & 2012 & $\begin{array}{l}\text { Primary infertility and } \\
\text { metrorrhagia }\end{array}$ & Adult GCT & $\begin{array}{l}\text { Omental metastatic } \\
\text { deposits on recurrence }\end{array}$ & $\begin{array}{l}\text { Recurrence in } \\
\text { left ovary and } \\
\text { omentum } 4 \text { years } \\
\text { after diagnosis }\end{array}$ \\
\hline 4 & 35 & 2016 & Amenorrhea & $\begin{array}{l}\text { Adult GCT } \\
\text { Mitotic Activity: } 3 \mathrm{MF} / 10 \mathrm{HPF}\end{array}$ & $\begin{array}{l}\text { Positive peritoneal } \\
\text { cytology }\end{array}$ & $\begin{array}{l}\text { No recurrence to } \\
\text { date }\end{array}$ \\
\hline 5 & 54 & 2013 & PMB & $\begin{array}{l}\text { Adult GCT } \\
\text { Mitotic activity: } 2 \mathrm{MF} / 10 \mathrm{HPF}\end{array}$ & $\begin{array}{l}\text { Endometrial polyps. } \\
\text { Weakly-proliferative } \\
\text { endometrium }\end{array}$ & $\begin{array}{l}\text { No recurrence to } \\
\text { date }\end{array}$ \\
\hline 6 & 58 & 2015 & $\begin{array}{l}\text { PMB and pelvic mass on } \\
\text { examination }\end{array}$ & Adult GCT (right ovary) & $\begin{array}{l}\text { Left ovarian dermoid. } \\
\text { Endometrial } \\
\text { hyperplasia with } \\
\text { intraepithelial neoplasia }\end{array}$ & $\begin{array}{l}\text { No recurrence to } \\
\text { date }\end{array}$ \\
\hline 7 & 59 & 1996 & $\begin{array}{l}\text { Abdominal pain and decreased } \\
\text { appetite }\end{array}$ & $\begin{array}{l}\text { Adult GCT with sarcomatoid } \\
\text { areas }\end{array}$ & N/A & $\begin{array}{l}\text { Recurrence in } \\
\text { mediastinum and } \\
\text { peritoneum }\end{array}$ \\
\hline 8 & 67 & 2013 & $\begin{array}{l}\text { PMB and ovarian cyst on } \\
\text { ultrasonography }\end{array}$ & Adult GCT & $\begin{array}{l}\text { Endometrial hyperplasia } \\
\text { without atypia }\end{array}$ & $\begin{array}{l}\text { No recurrence to } \\
\text { date }\end{array}$ \\
\hline
\end{tabular}

esis [3]. Ovarian juvenile GCTs have an interesting association with multiple enchondromatosis (Maffucci syndrome and Ollier disease) and are usually considered a leading diagnosis when an adnexal mass is identified in young females with these conditions.

Common presenting trends emerge in this case series. Females of reproductive age typically present with cycle irregularities and clinical or ultrasonographic findings of an adnexal cyst. Some patients, such as cases 2 and 4, present with secondary amenorrhea due to the suppression of follicle-stimulating hormone response to gonadotrophic-releasing hormone pulses by tumour-derived inhibin $B[4,5]$. The role of inhibin $B$, an ovarian heterodimeric glycoprotein, in the normal female menstrual cycle is to prevent further recruitment and growth of follicles close to ovulation.

On the other hand, the significant proportion of menopausal patients presented with postmenopausal bleeding. This is likely secondary to estrogenic elaboration by the GCT causing proliferative and hyperplastic changes in the endometrium, as in cases 5, 6 and 8 . These unopposed oestrogens may in turn lead to Type 1 endometrial carcinoma. A minority of tumours may also secrete androgens, and features of hyperandrogenaemia such as clitoromegaly or hirsutism may be present, although no such cases were seen in our case series [6].

A positive immunohistochemical stain for inhibin is a key diagnostic feature of GCT. As evident in the presented cases, adult-type GCTs exhibit an array of histological morphologies. Diffuse growth of oval cells with charac- teristic nuclear grooves ('coffee-bean' cells) are typical. Call-Exner body formation is typically seen in the microfollicular pattern of growth. The mitotic activity of these tumours is typically low, however increased mitotic activity of $\geq 4 \mathrm{MF} / 10 \mathrm{HPF}$ is associated with a worse prognosis and increased risk of recurrence [7]. Juvenile-type GCTs feature similar gross morphological features to their adult counterparts however typically exhibit a higher mitotic rate and lack the nuclear grooves seen in adult-type tumours. This relatively higher mitotic rate fits well with the apparent rapid cystic growth (and subsequent acute presentation) in the juvenile GCT cases of this series.

GCTs are considered neoplasms of low malignant potential. Unlike epithelial ovarian carcinoma, they have a relatively high detection rate with approximately $80 \%$ being diagnosed at stage I disease, leading to a reported five-year survival rate exceeding $90 \%$ [8]. This early detection rate is partly attributable to clinical manifestations secondary to inhibin and oestrogen expression. Recurrence following primary surgery occurs in approximately $25 \%$ of patients and can occur decades after first diagnosis, as shown in Case 7, in which the patient presented with symptoms of recurrence twenty-nine years after initial tumour resection [9]. Studies aiming to identify prognostic factors are limited not only by the relative rarity of these tumours but also by the long period for which follow-up would be required [10]. Serum markers of GCT include Inhibin B, which can be coupled with anti-Müllerian hormone in postmenopausal females. These have been shown to predate clinical recurrence by up to 13 months $[11,12]$. 
Clinical and pathological risk factors for recurrence in early stage GCTs have been mainly assessed in retrospective series and follow-up of patients identified through such series. A recent study by Thomakos and colleagues [13] retrospectively analysed 43 patients with ovarian GCT for possible risk factors associated with recurrence. Patients included in the study were mainly staged as IA (72.1\%) while 10 (23.3\%) were staged as IC, partly secondary to intraoperative cyst rupture. Two other cases were classified as stage IIB following surgical staging. Following multivariate analysis these investigators found tumour size, stage and mitotic index ( $\geq 4 \mathrm{MF} / 10$ HPF) to be independent predictors for recurrence. This puts the first two cases of this series at higher risk of recurrence. Both these cases had a high mitotic index (19 and 17 MF/10 HPF respectively) and both patients had experienced intraabdominal cyst rupture, upstaging the cases to FIGO IC. In fact, as detailed in Table 1, the first patient in this series experienced recurrence in the pouch of Douglas after 4 years.

Another study assessing recurrence patterns in GCTs was the Multicenter Italian Trials in Ovarian cancer (MITO-9) study by Mangili, et al. [14]. This study investigated 35 cases of recurrent GCT and found that despite improved recurrence-free survival, there was no difference in overall survival among patients receiving or not receiving chemotherapy after secondary surgery for recurrence and among the different relapse sites.

Surgical management for GCT cases constitutes fertility-preserving unilateral salpingo-oophorectomy, or TAH-BSO in patients with a completed family. Staging using peritoneal washings, omental and peritoneal sampling is also recommended however there is no consensus regarding the role of lymphadenectomy [15]. The value of postoperative adjuvant therapy for patients at high risk of recurrence has not been investigated by randomized control trials. Prolonged surveillance with periodic clinical, biochemical and radiologic investigations is imperative, given the tendency of late recurrence following initial surgical management [16].

\section{Conflict of Interest Statement}

There are no conflicts of interest (through affiliation or financial support) in this study.

\section{References}

1. Young RH (2005) Sex cord-stromal tumors of the ovary and testis: Their similarities and differences with consideration of selected problems. Mod Pathol 18: S81-S98.
2. Kanthan R, Senger J, Kanthan S (2012) The multifaceted granulosa cell tumours-myths and realities: A review. ISRN Obstet Gynecol 2012: 878635.

3. Shah SP, Köbel M, Senz J, Morin RD, Clarke BA, et al. (2009) Mutation of FOXL2 in granulosa-cell tumours of the ovary. N Engl J Med 360: 2719-2729.

4. Agha-Hosseini M, Aleyaseen A, Safdarian L, Kashani L (2009) Secondary amenorrhea with low serum luteinizing hormone and follicle-stimulating hormone caused by an inhibin A- and inhibin B-producing granulosa cell tumor. Taiwan J Obstet Gynecol 48: 72-75.

5. Kurihara S, Hirakawa T, Amada S, Ariyoshi K, Nakano H (2004) Inhibin-producing ovarian granulosa cell tumor as a cause of secondary amenorrhea: Case report and review of the literature. J Obstet Gynaecol Res 30: 439-443.

6. Niwa K, Yano R, Mori S, Yamaguchi Y, Narikawa N, et al. (2013) Androgenic adult granulosa cell tumor with secondary amenorrhea and elevated luteinizing hormone. Pathology Discovery 1: 9 .

7. Vimla N, Kumar L, Kumar S, Vijayaraghavan M, Bhatla N, et al. (2005) Granulosa cell tumours of ovary: Variables affecting prognosis. Indian Journal of Medical and Paediatric Oncology 26: 12-19.

8. Malmström H, Högberg T, Risberg B, Simonsen E (1994) Granulosa cell tumors of the ovary: Prognostic factors and outcome. Gynecol Oncol 52: 50-55.

9. Mangili G, Ottolina J, Gadducci A, Giorda G, Breda E, et al. (2013) Long-term follow-up is crucial after treatment for granulosa cell tumours of the ovary. Br J Cancer 109: 29-34.

10. Sehouli J, Drescher FS, Mustea A, Elling D, Friedmann W, et al. (2004) Granulosa cell tumor of the ovary: 10 years follow-up data of 65 patients. Anticancer Res 24: 1223-1229.

11. Koukourakis GV, Kouloulias VE, Koukourakis MJ, Zacharias GA, Papadimitriou C, et al. (2008) Granulosa cell tumor of the ovary: Tumor review. Integr Cancer Ther 7: 204-215.

12. Lyubimova NV, Beyshembaev AM, Kushlinskiy DN, Zordania KI, Adamyan LV (2011) Granulosa Cell Tumors of the Ovary and Inhibin B. Bull Exp Biol Med 150: 635-638.

13. Thomakos N, Biliatis I, Koutroumpa I, Sotiropoulou M, Bamias A, et al. (2016) Prognostic factors for recurrence in early stage adult granulosa cell tumor of the ovary. Arch Gynecol Obstet 294: 1031-1036.

14. Mangili G, Sigismondi C, Frigerio L, Candiani M, Savarese A, et al. (2013) Recurrent granulosa cell tumors (GCTs) of the ovary: A MITO-9 retrospective study. Gynecol Oncol 130: $38-42$.

15. Fotopoulou C, Savvatis K, Braicu E, Brink-Spalink V, Darb-Esfahani S, et al. (2010) Adult granulosa cell tumors of the ovary: Tumor dissemination pattern at primary and recurrent situation, surgical outcome. Gynecol Oncol 119: 285-290.

16. Stenwig J, Hazekamp J, Beecham J (1979) Granulosa cell tumors of the ovary. A clinicopathological study of 118 cases with long-term follow-up. Gynecol Oncol 7: 136-152. 


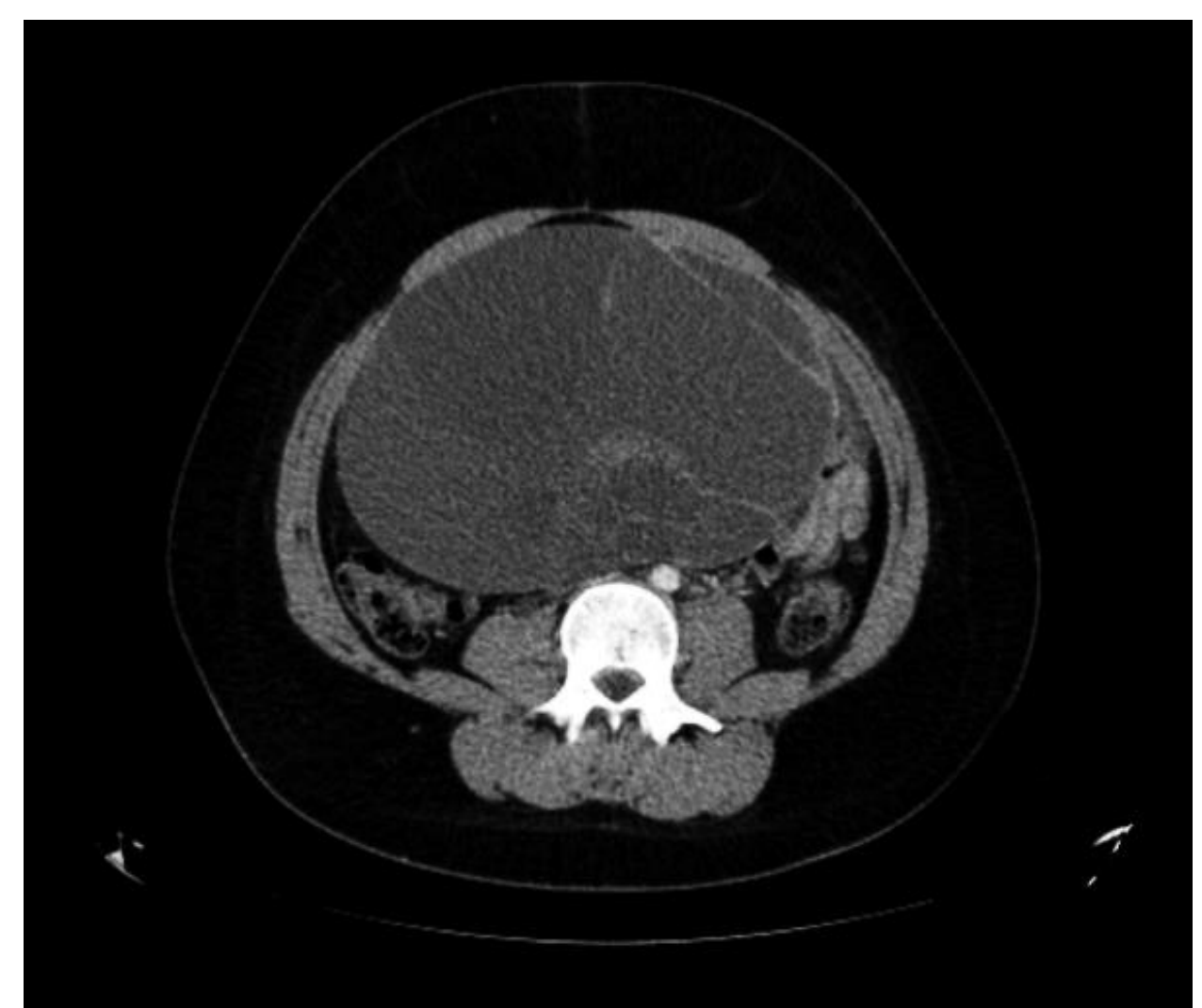

Figure S1: Axial CT image showing a multiseptated adnexal cyst with solid and cystic components as described in Case 2.

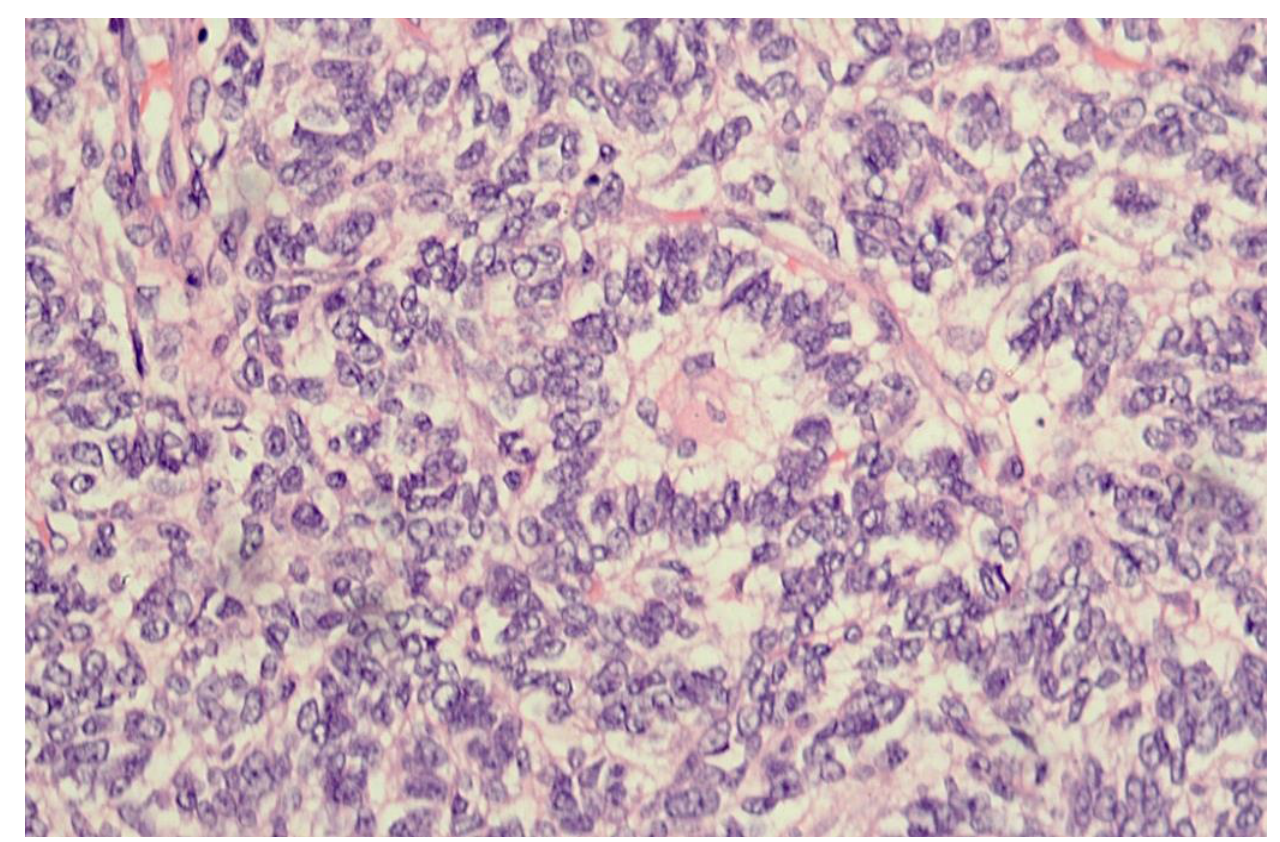

Figure S2: High power view showing a typical Call-Exner body, as seen in Case 8 (H\&E x400).

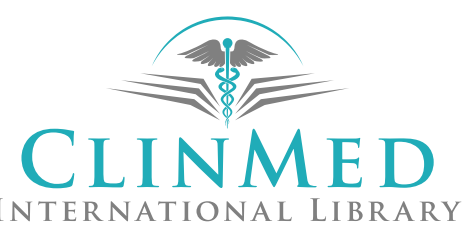

